\title{
BIOMASS OF COARSE WOODY DEBRIS FOLLOWING DISTURBANCE IN ROCKY MOUNTAIN CONIFEROUS FORESTS
}

\author{
DANIEL B. TINKER $\downarrow$ DENNIS H. KNIGHT \\ BOTANY DEPARTMENT $\downarrow$ UNIVERSITY OF WYOMING \\ LARAMIE
}

\section{$\downarrow \quad$ INTRODUCTION}

Primary productivity, the accumulation of nutrients, and other important ecosystem processes are largely dependent on the mineral soil organic matter that has developed during hundreds or thousands of years. In forest ecosystems, the decomposition of coarse woody debris, woody roots, twigs, leaves and micro-organisms is a primary source of this organic matter. Large quantities of coarse woody debris are typically produced following natural disturbances such as fires, pest/pathogen outbreaks, and windstorms, and make a significant contribution to the formation of soil organic matter (SOM). In contrast, timber harvesting often removes most of the coarse woody debris (CWD), which could result in a decrease in the quantity and a change in the quality of mineral soil organic matter.

The 1988 fires in Yellowstone National Park continue to provide an excellent opportunity to study the effects of fires of various intensities on ecosystem processes. Ecosystems develop under conditions that are constantly changing, but which remain within some range of natural variability. At present, national forest managers are uncertain as to the quantity of CWD which should be left in a stand following timber harvest in order to maintain levels of SOM which are within the range of natural variability. Little empirical data exist which help characterize the range of natural variability with regard to CWD in lodgepole pine forests, and it is therefore difficult to assess current timber harvesting practices in terms of how much CWD should be left at each site. We began a pilot study in late summer 1995 to begin to address this deficiency. A larger study of broader scope is planned for an additional two to three years, beginning this year, in 1996. This research will attempt to measure specific processes which include the distribution, decomposition, combustion by natural fires, and removal of CWD.

The specific objectives of our study are: i) compare the mass and distribution of coarse woody debris that remains following fires of varying intensities to that which remains following clearcutting in the Rocky Mountain Region; ii) estimate the amount of CWD that is combusted or converted to charcoal following fires of varying intensities in stands of varying stages of development; and iii) estimate the length of time necessary for every square meter of the forest soil to be affected by CWD under natural conditions.

\section{STUDY AREA}

Research sites for this project are located in lodgepole pine forests of central and southern 
Yellowstone National Park in northwestern Wyoming, and in the Medicine Bow National Forest in southeastern Wyoming.

All stands selected for sampling were at least 3 ha in size. Sites for the Yellowstone study were selected based on two important criteria: a chronosequence of post-fire ages ranging for 7 - 150 years located in stands of similar habitat type, and a series of stands which represent the range of burn intensities of the 1988 fires, including unburned stands. Additional stands were sampled this year to compliment the stands sampled in 1995 . Clearcuts in the Medicine Bow National Forest were all harvested between 1991-1993 and were subjected to roller-chopping, a post-harvest slash treatment which fragments and redistributes the slash somewhat evenly around the clearcut. Uncut stands in the Medicine Bow were located as near to the clearcuts as possible, and were chosen to be similar in stand density and age to the pre-harvest characteristics of the clearcuts. The climate and vegetation types between the two regionallyseparated sites are similar enough to make reasonable comparisons regarding biomass and cover estimates.

\section{FIELD METHODS}

Tree age data, either from tree cores or annual rings on stumps, were used to estimate stand ages and disturbance histories. For all stands in both of the study areas, the following data were obtained: mass $(\mathrm{Mg} / \mathrm{ha})$ and percent cover of standing and detrital bolewood and large branch wood by size class, decay class, and approximate time of origin. The biomass estimates for standing live and dead trees and stumps were obtained using the planar intercept method (Brown 1974). Mass of standing dead and live bolewood, woody roots, and root crowns was estimated by using allometric equations which utilize bole diameters (Pearson et al. 1984). Percent cover of standing and detrital bolewood was calculated from field maps created for two $20 \times 20 \mathrm{~m}$ areas in each stand. These maps contained scaled drawings of all dead and downed woody detritus by decay class, all sound and downed woody detritus, and all standing live and dead trees and stumps. Initial sampling was performed in 1995 and 1996 in lodgepole pine (Pinus contorta var, latifolia) stands in the Medicine Bow National Forest, where timber harvesting has occurred for decades. Measurements of standing and downed CWD and woody roots were made in stands of lodgepole pine on sites of similar substrate and at similar elevation in Yellowstone National Park, and these measurements were compared to the Medicine Bow estimates.

\section{RESULTS AND DISCUSSION}

Initial estimates of CWD biomass in the two study areas indicate that almost twice as much CWD may remain following intense fires than that which remains following clearcutting. However, much of the larger amount of CWD remaining following fires is attributed to the large number of dead-standing trees which are not consumed during fires, but are killed and eventually fall to the ground. In fact, there were no differences in downed woody material of any size class between clearcuts and burned stands. It should be noted, however, that harvested stands in this study have only been subjected to a single timber harvest, and the present levels of large, downed bolewood, especially wood inherited from the previous standreplacing fire, would likely decrease following repeated harvesting. Clearcuts may contain higher amounts of fine woody detritus $(<7.5 \mathrm{~cm}$ in diameter) than do burned stands, probably due to the post-harvest practice of leaving the majority of the slash on the site to be mechanically scattered and roller chopped, and the fact that most of the small woody material is typically consumed by moderate to severe fires.

When comparing clearcut stands to uncut stands, with the exception of the $8-20 \mathrm{~cm}$ size class of downed woody detritus, there were no significant differences in total downed wood.

Notably, one stand in YNP which burned in 1975 and again in 1988 contained significantly less CWD than either clearcuts or stands which only burned a single time, suggesting that fire return interval may be an important controlling factor in CWD dynamics in natural systems.

Additional field work will be conducted during the summer of 1997 to complete the data sets from which to base the comparisons, and to increase the spatial extent and replication of the samples. Also, prior to that time, we will design a new sampling strategy to be implemented during the summer of 1997, which will address our second objective by quantifying the amount of wood 
consumed by fires of varying intensities, as well as the amount of old wood which is converted to charcoal but is still present on the forest floor. These estimates will allow for more accurate predictions of the amounts of CWD which remain following natural fires in lodgepole pine forests.

With regard to our third objective, we are presently digitizing the field study maps which will be used for percent cover calculations, and are developing a spatially-explicit simulation model which, using the digitized maps, will model the dynamics of CWD following disturbances such as fire and timber harvesting over the course of decades to centuries. These results will be reported when completed.

\section{LITERATURE CITED}

Brown, James K. 1974. Handbook for inventorying downed woody material USDA Forest Service General Technical Report INT-16. Intermountain Forest and Range Experiment Station. Ogden, UT. $24 \mathrm{pp}$.

Pearson, J.A., T. J. Fahey, and D.H. Knight. 1984. Biomass and leaf area in contrasting lodgepole pine forests. Can. J. For. Res. 14:259-265. 